\title{
Efektivitas Ekstrak Etanol Biji Alpukat (Persea americana Mill.) Terhadap Kadar Glukosa Darah Tikus Putih Jantan (Rattus Novergicus) Model Hiperkolesterolemia-Diabetes
}

\author{
(Effectiveness of Ethanol Extract of Avocado Seeds (Persea americana mill.) on Blood \\ Glucose Levels of Male White Rat (Rattus novergicus) Hipercolesterolemia-diabetes \\ Model)
}

\author{
Recky Patala $^{1 *}$, Niluh Puspita Dewi ${ }^{1}$, Meilinda Handayani Pasaribu ${ }^{1}$

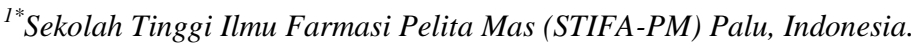 \\ E-mail: reckyfarmasi@gmail.com
}

Article Info:

Received: 10 Oktober 2019

in revised form: 10 Oktober 2019

Accepted: 24 Oktober 2019

Available Online: 02 Maret 2020

Keywords:

Avocado Seeds

Hiperkolesterolemia-diabetic

Blood Glucose Levels.

Corresponding Author:

Recky Patala

Sekolah Tinggi Ilmu Farmasi

Pelita Mas (STIFA-PM)

Palu

Indonesia

email: reckyfarmasi@gmail.com

\begin{abstract}
Diabetes mellitus is a metabolic disorder characterized by increased blood glucose levels due to a deficiency of insulin secretion or when insulin resistance occurs. Herbal medicine is one alternative method that can be used to control blood glucose levels and prevent complications of diabetes mellitus. One of the medicinal plants is avocado seeds (Persea americana Mill.) The active compounds contained in avocado seeds that have antidiabetic activity are flavonoids, alkaloids, tannins and saponins. This study aims to determine the content of secondary metabolites in the extract of avocado seed, the effect of extract of avocado seed and the dose of extract of avocado seed that is effective in lowering blood glucose levels. This research was a laboratory experiment using a modified randomized controlled pretest and posttest group design. Test animals used were 30 rats which were divided into six treatment groups, namely normal control, negative control, positive control, a dose of 250,300 and $350 \mathrm{mg} / \mathrm{kg}$ groups. The results showed that extract of avocado seed contained secondary metabolites: flavonoids, alkaloids, saponins, and tanins; extract of avocado seed gave effect to decrease blood glucose levels; extract of avocado seed with a dose of $350 \mathrm{mg} / \mathrm{kg}$ was effective in lowering blood glucose levels with an avarage decrease of $99,8 \mathrm{mg} / \mathrm{dL}$.
\end{abstract}

Copyright () 2019 JFG-UNTAD

This open access article is distributed under a Creative Commons Attribution (CC-BY-NC-SA) 4.0 International license.

How to cite (APA $6^{\text {th }}$ Style):

Patala, R., Dewi, N. P., \& Pasaribu, M. H. (2020). Efektivitas Ekstrak Etanol Biji Alpukat (Persea americana Mill.) Terhadap Kadar Glukosa Darah Tikus Putih Jantan (Rattus Novergicus) Model Hiperkolesterolemia-Diabetes. Jurnal Farmasi Galenika :Galenika Journal of Pharmacy (e-Journal), 6(1), 7-13. doi:10.22487/j24428744.2020.v6.i1.13929 


\section{ABSTRAK}

Diabetes melitus merupakan suatu kelainan metabolisme yang ditandai dengan meningkatnya kadar glukosa darah akibat dari suatu defesiensi sekresi insulin atau ketika terjadi resistensi insulin. Pengobatan herbal merupakan salah satu cara alternatif yang dapat digunakan untuk mengontrol kadar glukosa darah dan mencegah timbulnya komplikasi diabetes melitus. Salah satu tanaman yang berkhasiat sebagai obat yaitu biji alpukat (Persea americana Mill.) Senyawa aktif yang terkandung pada biji alpukat yang memiliki aktivitas sebagai antidiabetes adalah flavonoid, alkaloid, tanindan saponin. Penelitian ini bertujuan mengetahui kandungan senyawa metabolit sekunder pada ekstrak biji alpukat, efek pemberian ekstrak biji alpukat dan menentukan dosis ekstrak biji alpukat yang efektif dalam menurunkan kadar glukosa darah. Penelitian ini merupakan penelitian eksperimen laboratorium dengan menggunakan rancangan penelitian modifikasi pretest and posttest randomized controlled group design. Hewan uji yang digunakan sebanyak 30 ekor tikus dibagi menjadi 6 kelompok perlakuan, yaitu kontrol normal, kontrol negatif, kontrol positif, dosis $250 \mathrm{mg} / \mathrm{kgBB}, 300 \mathrm{mg} / \mathrm{kgBB}$ dan 350 $\mathrm{mg} / \mathrm{kgBB}$. Hasil penelitian menunjukkan bahwa ekstrak biji alpukat mengandung senyawa metabolit sekunder flavonoid, alkaloid, saponin, dan tanin; ekstrak biji alpukat memberikan efek terhadap penurunan kadar glukosa darah; ekstrak biji alpukat pada dosis $350 \mathrm{mg} / \mathrm{kgBB}$ merupakan dosis yang efektif dalam menurunkan kadar glukosa darah dengan nilai rata-rata penurunan sebesar $99,8 \mathrm{mg} / \mathrm{dL}$.

Kata kunci: Biji alpukat, Hiperkolesterolemia-diabetes, Kadar glukosa darah.

\section{PENDAHULUAN}

Diabetes melitus merupakan suatu kelainan metabolisme karbohidrat, yang ditandai dengan hiperglikemia abnormal sebagai akibat dari suatu defisiensi sekresi insulin, berkurangnya aktivitas fungsi biologis insulin atau adanya resistensi insulin dan kemudian sel-sel $\beta$ menunjukan gangguan pada sekresi insulin fase pertama, artinya sekresi insulin gagal mengkompensasi resistensi insulin (DM tipe 2) atau kekurangan insulin secara absolut (DM tipe 1) (Tandi et al., 2016). International Diabetes Federation (IDF) tahun 2015 menyebutkan bahwa lebih dari setengah juta anak-anak berusia $\leq 14$ tahun hidup dengan penyakit diabetes tipe 1 dan sekitar 415 juta orang dewasa di dunia berusia 20-79 tahun hidup dengan diabetes tipe 2, IDF juga menyebutkan bahwa 318 orang mengalami gangguan toleransi glukosa. World Health Organization (WHO) 2016 menyebutkan jumlah orang yang hidup dengan diabetes hampir empat kali lipat sejak tahun 1980 yaitu 422 juta, sebagian besar hidup di negara berkembang.

Pengobatan tradisional merupakan salah satu cara alternatif yang dapat digunakan untuk mengontrol kadar glukosa darah dan mencegah timbulnya komplikasi diabetes melitus. Pengobatan herbal memiliki efek samping yang kecil jika digunakan pada dosis yang tepat dibandingkan dengan obat kimia, serta biaya yang relatif lebih murah dan mudah ditemukan (Wasito, 2012).

Salah satu tanaman yang berkhasiat sebagai obat yaitu biji alpukat (Persea americana Mill.) Senyawa aktif yang terkandung pada biji alpukat yang memiliki aktivitas sebagai antidiabetes adalah flavonoid, alkaloid, tanin dan saponin. Biji Alpukat memiliki berbagai macam kegunaan antara lain mengobati diare, sakit gigi, serta pengobatan kulit dan kecantikan. Minyak biji alpukat juga memiliki beberapa manfaat kesehatan salah satunya untuk menurunkan berat badan. Tanaman alpukat telah banyak diketahui memiliki khasiat sebagai antinflamasi dan analgetik. (Alhassan et al., 2012). Penelitian sebelumnya menyatakan bahwa ekstrak biji alpukat pada dosis $1200 \mathrm{mg} / \mathrm{kgBB}$ dapat menurunkan kadar glukosa darah tikus putih jantan dengan rata-rata penurunan 134,8 mg/dL (Yunita,2013). Ekstrak etanol $70 \%$ biji alpukat juga memiliki aefek antioksidan dengan nilai $\mathrm{IC}_{50} 31,5 \mathrm{ppm}$. Senyawa fenolik dalam biji alpukat lebih besar dibanding dalam buah maupun daun alpukat (Sutrisna et al., 2015).

Berdasarkan uraian tersebut di atas maka perlu dilakukan penelitian tentang efek ekstrak biji alpukat terhadap penurunan kadar glukosa darah tikus putih jantan di induksi streptozotocin. Tujuan penelitian ini yaitu untuk mengetahui efek pemberian ekstrak etanol biji alpukat (Persea americana Mill.) dan 
menentukan dosis yang efektif terhadap penurunan glukosa darah tikus putih jantan (Rattus novergicus).

\section{METODE PENELITIAN}

\section{Alat dan Bahan}

Alat yang digunakan adalah ayakan nomor 40 mesh, batang pengaduk, bejana maserasi, blender (National), botol larutan stok, botol minum hewan uji, cawan porselin, corong kaca (Pyrex), erlenmeyer (Pyrex), gelas kimia $100 \mathrm{~mL}$ dan $1000 \mathrm{~mL}$ (Pyrex), gelas ukur $25 \mathrm{~mL}, 50 \mathrm{~mL}$, dan $100 \mathrm{~mL}$ (Pyrex), glukometer (Accu Chek), gunting, kandang hewan uji, mortir dan stamper, penangas air (Denville), pipet tetes, rak tabung, rotary vaccum evaporator (Eyela), spidol, spuit oral, spuit injeksi 3 $\mathrm{mL}$ (Terumo Syringe), tabung reaksi (Pyrex), tempat makan tikus, timbangan analitik (Ohaus), timbangan gram (Cook master). Bahan yang digunakan yaitu Air suling, alumunium foil, alkohol $70 \%$, asam klorida $2 \mathrm{~N}$, aqua pro injeksi, biji alpukat (Persea americana Mill.), besi (III) klorida $\left(\mathrm{FeCl}_{3}\right)$,citrate-buffer saline, dragendrof LP, etanol 96\%, etanol 95\%, handskund, kapas, kertas label, kertas saring, lakban, masker, Na.CMC, natrium klorida $(\mathrm{NaCl}) 10 \%$, pakan standar, serbuk magnesium P, streptozotocin, strip glukotest (Accu check), tablet metformin dan tissue.

\section{Metode}

Penelitian ini menggunakan metode eksperimental dengan rancangan modifikasi pre and post test randomized controlled group design.

\section{Persiapan bahan uji}

Bahan yang digunakan dalam penelitian ini yaitu biji alpukat (Persea americana Mill.) yang diperoleh di daerah Kecamatan Palu Selatan Kota Palu. Determinasi tanaman dilakukan di UPT. Sumber Daya Hayati Sulawesi, Universitas Tadulako. Biji alpukat tersebut dikering anginkan, kemudian dihaluskan sampai diperoleh serbuk simplisia kering. Sebanyak $1 \mathrm{Kg}$ serbuk simplisia kering biji alpukat dimaserasi dengan etanol 96\% sebanyak 5 Liter selama 3 x 24 jam, kemudian disaring. Selanjutnya filtrat diuapkan dengan menggunakan rotary vaccum evaporator pada suhu $70^{\circ} \mathrm{C}$ dan dilanjutkan dengan menggunakan waterbath suhu $60^{\circ} \mathrm{C}$ hingga diperoleh hingga ekstrak kental.

\section{Uji Penapisan Fitokimia}

Ekstrak biji alpukat yang telah diperoleh kemudian dilakukan penapisan fitokimia terhadap adanya senyawa alkaloid, flavonoid, saponin dan tannin (Harborne, 1987).

\section{Pengujian Aktivitas Antidiabetes}

Hewan uji yang digunakan dalam penelitian ini yaitu tikus (Rattus novergicus) berjumlah 30 ekor, kemudian dibagi menjadi 6 kelompok dengan masing-masing kelompok berjumlah 5 ekor. Pengambilan darah dilakukan pada ekor masing-masing tikus untuk pemeriksaan kadar glukosa darah awal (baseline) untuk memastikan tikus yang digunakan normal sebelum hewan uji diberi perlakuan. Setelah diukur kadar glukosa darah awal diberikan pakan tinggi kolestesrol dengan komposisi standar $(80 \%)$, lemak babi (15\%), dan kuning telur bebek (5\%) dengan konsumsi sebanyak 20 gram/tikus selama 28 hari kemudian tikus diinduksi streptozotocin dengan $30 \mathrm{mg} / \mathrm{kgBB}$ secara intraperitoneal. . Hari ketujuh setelah penginduksian, tikus dipuasakan selama 16 jam kemudian mengukur kembali kadar glukosa darah tikus sesudah penginduksian. Setelah kadar glukosa darah puasa tikus telah mencapai keadaan hiperglikemia (> $200 \mathrm{mg} / \mathrm{dL}$ ), diberikan perlakuan peroral selama 14 hari yaitu sebagai berikut : 
Kelompok 1, sebagai kontrol normal, diberi pakan standar tanpa induksi.

Kelompok 2, sebagai kontrol negatif, diberikan larutan koloidal $\mathrm{Na} \mathrm{CMC}$ 0,5\% secara per oral setiap hari.

Kelompok 3, sebagai kontrol positif, diberikan suspensi metformin $45 \mathrm{mg} / \mathrm{kgBB}$ secara per oral setiap hari selama 14 hari.

Kelompok 4, sebagai kelompok uji, diberikan ekstrak etanol biji alpukat dengan dosis $250 \mathrm{mg} / \mathrm{kg} \mathrm{BB}$ secara per oral setiap hari.

Kelompok 5, sebagai kelompok uji, diberikan ekstrak etanol biji alpukat dengan dosis $300 \mathrm{mg} / \mathrm{kg} \mathrm{BB}$ secara per oral setiap hari.

Kelompok 6, sebagai kelompok uji, diberikan ekstrak etanol biji alpukat dengan dosis $350 \mathrm{mg} / \mathrm{kg} \mathrm{BB}$ secara per oral setiap hari.

Data pengukuran kadar glukosa darah sebelum dan setelah perlakuan yang diperoleh dicatat dan dianalisis.

\section{Analisis Data}

Hasil pengamatan berupa data kadar glukosa dara yang dianalisis secara statistik menggunakan uji non parametrik Kruskal-Wallis dengan uji lanjut Mann-Whitney pada tingkat kepercayaan 95\%. Data dianalisis menggunakan program SPSS 23.

\section{HASIL DAN PEMBAHASAN}

Hasil randemen yang diperoleh dari proses ekstraksi sebesar 3,037\%. Data hasil penapisan fitokimia ekstrak etanol biji alpukat dapat dilihat pada tabel 1 berikut :

Tabel 1. Hasil Penapisan Fitokimia Ekstrak Biji Alpukat

\begin{tabular}{ccc}
\hline No & Pengujian & Hasil \\
\hline 1 & Uji Alkaloid & + \\
2 & Uji Flavonoid & + \\
3 & Uji saponin & + \\
4 & Uji Tanin & + \\
\hline
\end{tabular}

Keterangan : (+) : Mengandung golongan senyawa yang diuji

Selama penelitian dilakukan pengamatan terhadap kadar glukosa darah tikus, baik sebelum induksi dan setelah hiperglikemia yang dilanjutkan dengan pemberian perlakuan selama 14 hari. Pada hari keH-35, H-42, dan H-49 dilakukan pengukuran kadar glukosa darah dalam setiap kelompok. Data rerata kadar glukosa darah hewan uji ditampilkan pada tabel 2 berikut : 
Tabel 2. Persentase Penurunan Kadar Glukosa Darah Pada H-35, H-42, dan H-49

\begin{tabular}{|c|c|c|c|c|c|c|}
\hline \multirow[t]{2}{*}{ Kelompok } & \multirow[t]{2}{*}{$\mathbf{N}$} & \multicolumn{3}{|c|}{$\begin{array}{c}\text { Kadar Glukosa Darah }(\mathrm{mg} / \mathrm{dL}) \text { Selama } 14 \text { Hari } \\
\text { Pengamatan }\end{array}$} & \multicolumn{2}{|c|}{$\%$ penurunan } \\
\hline & & $\begin{array}{c}\mathrm{H}-35 \\
(\text { pre-test })\end{array}$ & $\begin{array}{c}\mathrm{H}-42 \\
(\text { post-testI) }\end{array}$ & $\begin{array}{c}\mathrm{H}-49 \\
\text { (post-test II) }\end{array}$ & (post-test I) & (post-test II) \\
\hline $\begin{array}{l}\text { Kontrol } \\
\text { Normal }\end{array}$ & 5 & $90.2 \pm 7.94$ & $101.8 \pm 6.97$ & $90.6 \pm 7.02$ & $-12 \%$ & $0 \%$ \\
\hline Kontrol Negatif & 5 & $249.2 \pm 40.60$ & $232.6 \pm 43.75$ & $226.8 \pm 30.89$ & $6 \%$ & $8 \%$ \\
\hline Kontrol Positif & 5 & $297 \pm 26.76$ & $97.6 \pm 4.21$ & $78 \pm 7.07$ & $67 \%$ & $73 \%$ \\
\hline $\begin{array}{c}\text { Ekstrak Etanol } \\
\text { Biji Alpukat } \\
250 \text { mg/kgBB }\end{array}$ & 5 & $256 \pm 57.08$ & $144.4 \pm 40.36$ & $121.4 \pm 22.74$ & $44 \%$ & $53 \%$ \\
\hline $\begin{array}{c}\text { Ekstrak Etanol } \\
\text { Biji Alpukat } \\
300 \mathrm{mg} / \mathrm{kgBB}\end{array}$ & 5 & $282.8 \pm 32.48$ & $130.8 \pm 29.79$ & $119.4 \pm 21.36$ & $53 \%$ & $57 \%$ \\
\hline $\begin{array}{c}\text { Ekstrak Etanol } \\
\text { Biji Alpukat } \\
\text { 350 mg/kgBB }\end{array}$ & 5 & $288 \pm 16.35$ & $113.6 \pm 13.70$ & $99.8 \pm 14.30$ & $60 \%$ & $65 \%$ \\
\hline
\end{tabular}

Grafik profil kadar glukosa darah tikus sebelum induksi (hari ke-0), setelah hipergilkemia (hari ke-35) dan setelah hari ke-42 dan 49 pemberian ekstrak biji alpukat dengan berbagai variasi dosis (Gambar 1) adalah sebagai berikut.:

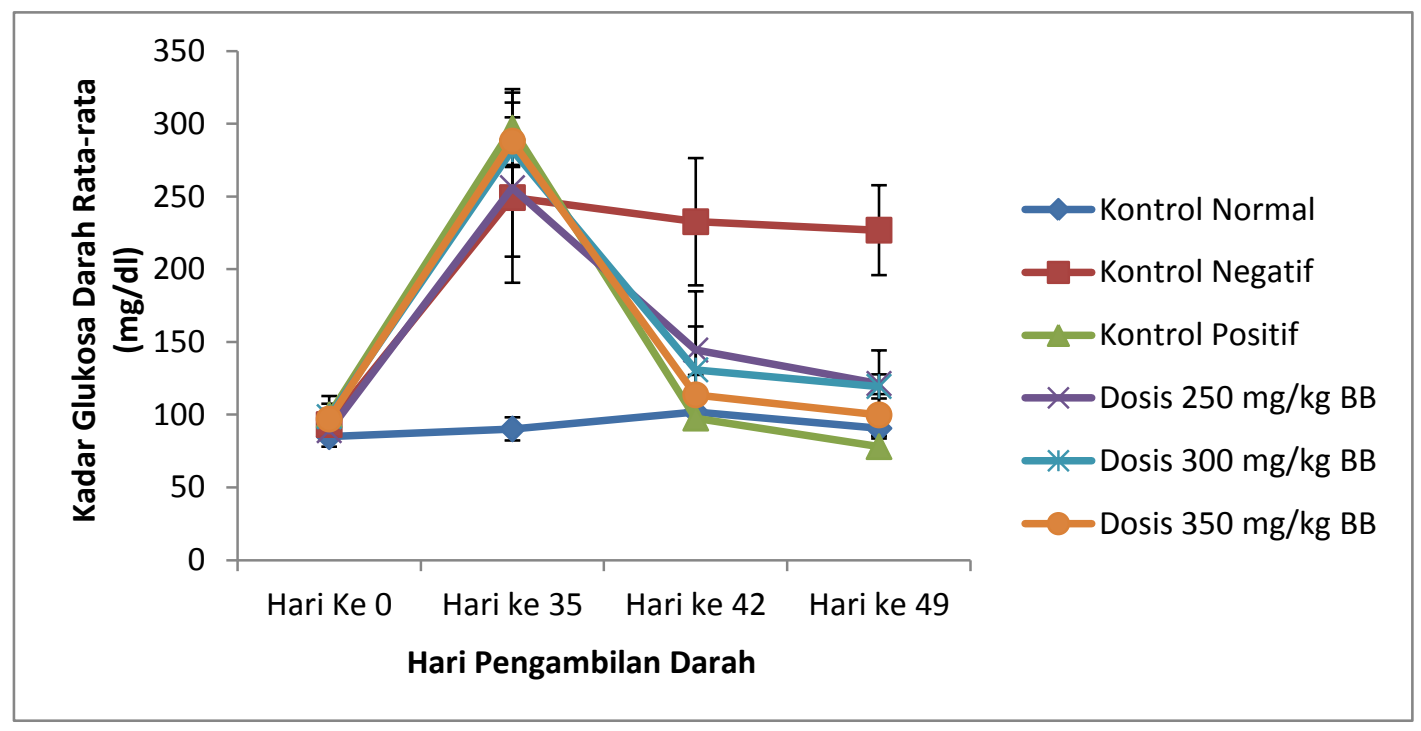

Gambar 1. Profil rerata hasil pengukuran kadar glukosa darah pada tikus

Hasil pengukuran kadar glukosa darah hari ke-0 menunjukkan kadar glukosa darah rata-rata semua kelompok perlakuan berkisar $84,8-99,8 \mathrm{mg} / \mathrm{dL}$, kadar glukosa darah tersebut dinyatakan normal, karena berada dalam rentang $50-135 \mathrm{mg} / \mathrm{dL}$ (Azhari et al., 2016).

Hasil pengukuran pada hari ke-35 menunjukkan kadar glukosa darah rata-rata semua kelompok perlakuan berkisar antara 90,2- $297 \mathrm{mg} / \mathrm{dL}$. Kenaikan kadar glukosa darah disebabkan pemberian streptozotocin dosis $30 \mathrm{mg} / \mathrm{kgBB}$ secara i.p. Mekanisme kerja streptozotocin menyebabkan hiperglikemia dengan cara streptozotocin masuk ke sel $\beta$ pankreas melalui glucose transporter (GLUT 
2) dan menginhibisi siklus krebs menginduksi (nitrit oxide) NO sehingga menyebabkan kerusakan DNA. Gugus alkil yang terdapat pada streptozotocin menyebabkan alkalisasi DNA. Alkalisasi tersebut akan mengaktifan poli (ADP - ribosilasion) yang membuat penurunan Nikotinamida Adenosin (NAD) dan (adenosin trifosfat) ATP yang menyebabkan kerusakan pada sel $\beta$ pankreas (Suryani, 2013).

Hasil pengukuran pada hari ke-42 menunjukkan kadar glukosa darah rata-rata semua kelompok perlakuan berkisar antara 97,6 - 232,6 mg/dL. Hal ini menunjukkan bahwa adanya penurunan kadar glukosa darah pada semua kelompok perlakuan kecuali kontrol normal dan kontrol negatif. Kontrol positif menunjukkan adanya penurunan kadar glukosa darah mendekati nilai normal dengan hasil persentase penurunan kadar glukosa darah sebesar 67\%, sedangkan kelompok dosis $250 \mathrm{mg} / \mathrm{kgBB}$ belum mencapai kadar glukosa darah normal dengan persentase sebesar 44\%, dosis $300 \mathrm{mg} / \mathrm{kgBB}$ dan dosis $350 \mathrm{mg} / \mathrm{kgBB}$ menunjukkan adanya penurunan kadar glukosa darah mencapai kadar glukosa darah normal dengan hasil persentase penurunan berturut-turut sebesar 53\% dan $60 \%$.

Hasil pengukuran pada hari ke-49 menunjukkan kadar glukosa darah rata-rata semua kelompok perlakuan berkisar antara $78-226,8 \mathrm{mg} / \mathrm{dL}$. Hal ini menunjukkan bahwa adanya penurunan kadar glukosa darah pada semua kelompok perlakuan kecuali kontrol normal dan kontrol negatif. Kelompok perlakuan ekstrak etanol biji alpukat dosis 250, 300, $350 \mathrm{mg} / \mathrm{kg}$ BB memberikan efek menurunankan kadar glukosa darah setelah 14 hari perlakuan. Persentase penurunan kadar glukosa darah pada kelompok ekstrak etanol biji alpukat dosis $250 \mathrm{mg} / \mathrm{kg} \mathrm{BB}, 300 \mathrm{mg} / \mathrm{kg} \mathrm{BB}$, $350 \mathrm{mg} / \mathrm{kg}$ BB masing-masing sebesar 53\%, 57\%, dan $65 \%$ sedangkan kontrol positif (metformin) sebesar $73 \%$. Hasil uji statistik non parametrik menunjukkan adanya perbedaan yang signifikan dari semua kelompok perlakuan. Kelompok dosis $350 \mathrm{mg} / \mathrm{KgBB}$ memberikan perbedaan yang signifikan bila dibandingkan dengan kelompok dosis $250 \mathrm{mg} / \mathrm{KgBB}$ dan $300 \mathrm{mg} / \mathrm{KgBB}$ dalam memberikan efek penurunan kadar glukosa darah. Kelompok dosis $350 \mathrm{mg} / \mathrm{KgBB}$ memberikan nilai rata-rata penurunan kadar glukosa darah tikus sebesar $99,8 \mathrm{mg} / \mathrm{dL}$. Adanya efek penurunan kadar glukosa darah disebabkan karena kandungan senyawa metabolit sekunder seperti tanin, saponin, flavanoid, dan alkaloid. Aktivitas antiinflamasi senyawa flavonoid, serta aktivitas antioksidan dapat mencegah dan menghentikan kerusakan sel beta pankreas lebih lanjut. Sedangkan, dimungkinkan alkaloid berperan dalam regenerasi sel, dengan memulihkan sel beta pankreas yang mengalami kerusakan parsial (Gupta et al., 2006). Saponin dapat menstimulasi sekresi insulin dari sel beta pankreas (Patel et al., 2012; Murray, et al., 2003). Pulihnya sel beta pankreas diharapkan akan memulihkan fungsinya dalam memproduksi insulin. Peningkatan jumlah insulin di dalam tubuh akan meningkatkan jumlah glukosa darah yang masuk ke dalam sel, sehingga terjadi penurunan kadar glukosa darah.

\section{KESIMPULAN}

Adapun kesimpulan yang diperoleh dalam penelitian ini bahwa ekstrak etanol biji alpukat (Persea americana Mill.) mampu memberikan efek dalam menurunkan kadar glukosa darah tikus putih jantan (Rattus norvegicus) yang diinduksi streptozotocin dengan dosis yang efektif dalam menurunkan kadar glukosa darah tikus putih jantan (Rattus norvegicus) yaitu dosis $350 \mathrm{mg} / \mathrm{kgBB}$ dengan nilai rata-rata penurunan 99,8 $\mathrm{mg} / \mathrm{dL}$. Perlu dilakukan standarisasi ekstrak dengan parameter spesifik dan nonspesifik untuk menentukan kualitas dari ekstrak etanol biji alpukat (Persea americana Mil.).

\section{DAFTAR PUSTAKA}

Alhassan, M. S., Sule, M. K., Atiku, A. M., Wudil, H., Abubakar, S. A., \& Mohammed. (2012). Effects of aqueous avocado pear (Persea americana Mill) seed extract on alloxan induced diabetes rats. Department of Biochemistry Bayero University. Kano, 2, 5.

Azhari, D. M., Yuliet, Y., \& Khaerati, K. (2016). Uji Aktivitas Serbuk Jamur Tiram Putih (Pleurotus ostreatus (Jacq.) P.Kumm) Terhadap Kadar Glukosa Darah Pada Model Hewan 
Hiperkolesterolemia-Diabetes. Jurnal Farmasi Galenika (Galenika Journal of Pharmacy) (eJournal), 2(2), 96-102.

Gupta, M., \& Neera, S. (2006). Regeneration of beta Cells in Islet of Langerhans of Pancreas of Alloxan Diabetic Rats by Acetone Extract of Momordica charantia (Linn) (bitter gourd) Fruits. Indian Journal of Experimental Biology, 45, 1055-1062.

Harborne, J. B. (1987). Metode Fitokimia Penuntun Cara Modern Menganalisis. Tumbuhan. Bandung: Penerbit ITB.

Internasional Diabetes Federation. 2015. IDF Diabetes Atlas. Edisi 7. Hal 9, 17, 28-29, 51.

Murray, R. K., Granner, D. K., Mayes, P. A., \& Rodwel, V. W. (2003). Biokimia Harper (Vol. 25). Jakarta: Penerbit Buku Kedokteran EGC.

Patel, D., Kumar, R., Laloo, D., \& Hemalatha, S. (2012). Natural Medicines From Plant Source Used For Therapy of Diabetes Mellitus: An Overview of Its Pharmacological Aspects. Asian Pacific Journal of Tropical Disease, 239-250.

Suryani, N., Tinny E.H., \& Aulanni'am. (2013). Pengaruh Ekstrak Metanol Biji Mahoni Terhadap Peningkatan Kadar Insulin, Penurunan Ekspresi TNF- $\alpha$ dan Perbaikan Jaringan Pankreas Tikus Diabetes. Jurnal Kedokteran Brawijaya, 27(3), 137-145.

Sutrisna, E., Azizah, T., \& oktaria, Y. E. (2015). The hypoglicemic effect of avocado seed (Persea americana mill) and histophatologic profile. Department of Pharmacology of Faculty of Medicine of Universitas Muhammadiyah Surakarta. Surakarta

Tandi, J., Muthi'ah, H. Z., Yuliet., \& Yusriadi. (2016). Efektivitas Ekstrak Daun Gedi Merah Terhadap Glukosa Darah, Malondialdehid, 8-Hdroksi-Deoksiguanosin, Insulin Tikus Diabetes. J. Trop Pharm. Chem, 3(4).

Wasito, H. (2012). Obat Tradisional Kekayaan Indonesia. Yogyakarta: Graha Ilmu. pp 12-17.

World Health Organization (WHO). 2016. Global report on diabetes. pp. 6, 23-25.

Yunita, E. O. (2013). Uji Aktivitas Antidiabetes Ekstrak Etanol Biji Alpukat (Persea Americana Mill) terhadap Tikus Galur Wistar yang Diinduksi Aloksan. Jurnal Farmasi. 